\title{
BATS (CHIROPTERA) IN THE COLLECTION OF THE ZOOLOGICAL MUSEUM OF LVIV UNIVERSITY, UKRAINE
}

\author{
I. Shydlovskyy ${ }^{1}$, A. Zatushevsky ${ }^{1}$, O. Kusnezh ${ }^{2}$ \\ ${ }^{I}$ Zoological Museum, Ivan Franko National University of Lviv (Lviv, Ukraine) \\ ${ }^{2}$ Ukrainian Centre for Bat Protection, Lviv Division (Lviv, Ukraine)
}

Correspondence to: I. Shydlovskyy; Zoological Museum, Ivan Franko National University of Lviv, Hrushevsky St. 4, Lviv, 79005 Ukraine;

e-mail:zoomus@franko.lviv.ua

\begin{abstract}
Bats (Chiroptera) in the collection of the Zoological Museum of Lviv University, Ukraine. - I. Shydlovskyy, A. Zatushevsky, O. Kusnezh. - The theriological collection of the Zoological Museum of Ivan Franko National University of Lviv was amassed during 142 years. It has over 3,800 exhibits, among which $343(9 \%)$ are bats (Chiroptera) that belong to 32 species. The bat collection is represented by study skins ( 254 exhibits) which are being preserved in 22 special boxes. Stuffed and almost all fluid-preserved specimens of bats are presented only in the exposition. Besides, there are 6 skeletons and 11 skulls in the collection, which belong to at least 9 species of bats. The main part of the collection was gathered in Western Ukraine, and only a few samples originate from the South and East of Ukraine. In particular, the type series of Khazarian serotine Eptesicus lobatus Zagorodniuk, 2009 was brought from Eastern Ukraine. Tropical species are also presented in the collection: Hipposideros caffer, Epomophorus labiatus, Pteropus vampyrus, and species of the genera Neoromicia and Rousettus. The bat collection was amassed during 1900-2015. It widely represents the bat fauna of the Carpathian region and Transcarpathian lowland.
\end{abstract}

Key words: bats, collections, zoological museum, Lviv University.

Рукокрилі (Chiroptera) у колекції Зоологічного музею Львівського університету. - І. В. Шидловський, А. Т. Затушевський, О. В. Кусьнеж. - Теріологічна колекція Зоологічного музею ЛНУ ім. І. Франка зібрана упродовж 142 років та налічує понад 3800 музейних зразків, з яких 343 зразки, або $9 \%$ - рукокрилі (Chiroptera) 32 видів. За типами музейних зразків колекція представлена тушками (254 екз.), які зберігаються у 22 спеціальних коробках. Опудала та майже всі мокрі препарати кажанів представлені в експозиції. Крім того, у колекції зберігаються шість скелетів та 19 черепів, що належать не менше ніж 9 видам кажанів. Основна частина колекції зібрана в межах західних областей України і лише поодинокими зразками представлено південь та схід. Зі сходу України, зокрема, є типовий матеріал пергача донецького, Eptesicus lobatus Zagorodniuk, 2009. Тропічні види представлені у колекції видами Hipposideros caffer, Epomophorus labiatus, Pteropus vampyrus, представниками родів Neoromicia та Rousettus. Хронологічно колекція зібрана упродовж 1900-2015 рр. Вона широко репрезентує хіроптерофауну регіону Карпат та Закарпатської низовини.

Ключові слова: кажани, колекції, зоологічний музей, Львівський університет.

\section{Introduction}

The Zoological Museum of Ivan Franko National University of Lviv (ZMD) with its collections is a unique asset of natural science, which makes possible to accumulate materials that cannot be collected in a short period of time. It also ensures the preservation of collection samples of different age, as well as animals collected in different parts of their range. At the same time, it allows processing materials related to rare and endangered species, which populations are too small to be investigated even by temporal extraction of individuals from the natural environment. Due to this feature, museums (collections) provide the opportunity to fully study and compare the samples that cannot be obtained or collected during a scientific course study or a research project, which are often limited 
by a small timeframe, poor funding, or the objects to reach are in different and often remote parts of the range.

One of these animal groups are the chiropterans that carry out a hidden, nightfall or night activity. Moreover, the places of their reproduction are so concealed that special equipment is often needed to finding them. In addition, all representatives of this group of the mammalian fauna of Ukraine are listed in the Red Data Book of Ukraine (2009).

The purpose of this paper is to show the quantitative and qualitative changes in the collection of bats that occurred during the 15-year period since the publication of its first synopsis (Bashta, Shydlovskyy, 2001) and the characterization of the collection published during the study of rare representatives of this order (Kusnezh, 2014). The electronic database of mammalian collections is being continuously updated for analysis (since 2010 in Excel format). It is a convenient tool for processing various data on individual museum objects and their series, as well as for searching and summarizing of specific information.

\section{The history of the collection's content and volume}

Reflecting on the history of mammalian species composition, it should be mentioned that the theriological collection of ZMD has been enriched for 142 years and it includes over 3,800 museum specimens, 343 or $9 \%$ of which are bats (Chiroptera).

Analyzing the collection of bats, we can claim its gradual enrichment in both quality and quantity. In particular, compared to 2001, when the revision of this collection was carried out, its abundance increased from 125 study skins and mounted specimens of 14 species to 194 museum samples of 25 species in 2010 (Zatushevskyy at al., 2010), and to 343 samples of 32 species by the end of 2016. This is without consideration of two unidentified specimens of Chiroptera, three unidentified specimens of the genus Neoromicia, two unidentified juveniles of Pipistrellus sp., and one specimen of Rousettus sp.

There are also 6 skeletons and 19 skulls of not less than 9 species in the bat collection, including skeletons of such species as the common noctule (Nyctalus noctula, Schreber, 1774) - 2 specimens, greater mouse-eared bat Myotis myotis (Borkhausen, 1797) - 1, pond bat M. dasycneme (Boie, 1825) - 1, Daubenton's bat M. daubentonii (Kuhl, 1817) - 1, and an unidentified Pipistrellus sp. Besides, there are skulls (1 specimen of each species) of the barbastelle Barbastella barbastellus (Schreber, 1774), brown long-eared bat or common long-eared bat, Plecotus auritus (Linnaeus, 1758), Natterer's bat Myotis nattereri (Kuhl, 1817), Nathusius' pipistrelle Pipistrellus nathusii (Keyserling and Blasius, 1839), as well as 3 specimens of the serotine bat Eptesicus serotinus (Schreber, 1774), 5 specimens of Nyctalus noctula, and 7 specimens of Eptesicus lobatus (Zagorodniuk, 2009).

The collection is represented mainly by study skins that are stored in special cardboard boxes sorted by species (Fig. 1 a). In particular, museum samples of this type are represented by 258 study skins, among which 104 with skulls, in 22 boxes.

Mounted bats are only in the exhibition and they represent the bat fauna of the western regions of Ukraine (common pipistrelle, Pipistrellus pipistrellus (Schreber, 1774), common bent-wing bat, Miniopterus schreibersii (Kuhl, 1817), parti-colored bat, Vespertilio murinus Linnaeus, 1758, Geoffroy's bat, M. emarginatus (E. Geoffroy, 1806). There is only one specimen from Romania, namely of the greater noctule bat, Nyctalus lasiopterus (Schreber, 1780), which is in the museum display.

Fluid-preserved specimens represent the fauna of tropical countries, in particular of Africa (Triaenops persicus (Dobson, 1871), Hipposideros commersoni (E. Geoffroy, 1813), Sundevall's roundleaf bat, H. caffer (Sandevall, 1846), Epomophorus labiatus (Temminck, 1837), Neoromicia nanus stampflii (Jentink, 1888) and Neoromicia sp.) and Southeastern Asia (the large flying fox, Pteropus vampyrus (Linnaeus, 1758) from Sri Lanka). A specimen of the genus Rousettus, distributed mainly in the southern hemisphere, is also exhibited.

In addition, a small amount of mummies and fluid-preserved specimens are also stored in the stock collection (Table 1). 


\section{Collection from Ukraine}

The majority of specimens in the bat exhibition were collected in Ukraine. In particular, bats from 7 of 24 oblasts and the Autonomous Republic of Crimea are represented. However, the quantitative distribution of samples' origin is not quite homogeneous. The largest collection came from Lviv and Zakarpattia oblasts ( $42.3 \%$ and $31.1 \%$, respectively), whereas such administrative units as the Autonomous Republic of Crimea and Ivano-Frankivsk oblast are represented only by a single specimen each. There are no samples from Chernivtsi and Khmelnytskyi oblasts. Concluding on the collection's record localities, the bulk of the collection is represented by specimens from the western regions and only few specimens from the southern (e.g., AR Crimea) and eastern regions of Ukraine (e.g., 8 item from Luhansk oblast). However, specimens from Luhansk oblast scientifically represent the most valuable part of the collection, including type series of Eptesicus lobatus (Zagorodniuk, 2009; Eptesicus lobatus Zagorodniuk, 2010) with a holotype and five paratypes (table 2).

\section{Chronology and geography of the collection}

Chronologically, the museum's collection of bats was amassed during 1902-2015. The very first specimen of the collection, a greater noctule bat, is dated to December 1902 (Fig. $1 \mathrm{~b}$ ). This is the only specimen dated to that time. This very specimen has repeatedly drawn attention of local scientists since Prof. K. Tatarinov (1956) wrote about it with the label "Opillya" stored in the collection of Lviv University. However, on the stand of the only copy available in our collection, on the left is a black ink indication, which states the name of the species "Vesperugo vespexus noctula" and its origin "18/12/1902 Dobrudza" and the composition "czaszka osobno" — the skull separately (in Polish). To the right of this indication is a stock-keeping unit, the Latin name " $N$. siculus," and the signature of K. Tatarinov made with pencil, apparently later than the original inscription. Between the Latin name and the professor's signature there is an illegible Polish inscription with small and narrow font, made by purple ink ("Polonensi?"). Therefore, the fact of discovery of the greater noctule bat in the West of Ukraine remains obscure.

In the monograph "The Mammals of Western Ukraine" (Tatarinov, 1956), at the end of the essay the author writes on the greater noctule bat the following: "Apparently, this kind of noctule bat in the western regions of the Ukrainian SSR is very rare, but in Dobrudja, according to verbal evidence that we have, it is [a] common [species]". In our opinion, this is another confirmation that our specimen of the greater noctule bat comes from the territory of Romania, namely from Dobrudja, and therefore it was not discovered in western Ukraine.
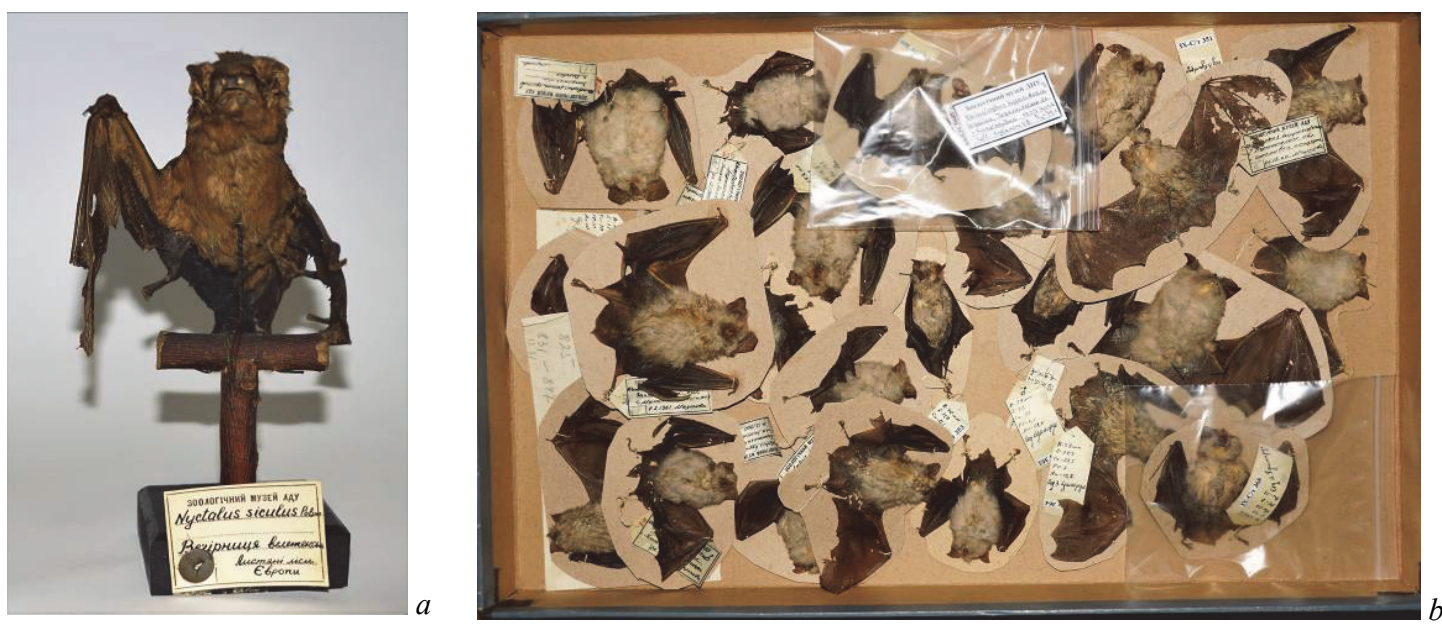

Fig. 2. Bats in the collection of ZMD: $a$ - one of the oldest specimens of bats in the Museum, Nyctalus lasiopterus; $b$ - a box with study skins of bats as an example of their storing in the Museum. Photo by A. Zatushevsky.

Рис. 2. Кажани в колекції ЗМД: $a$ - один із найстаріших зразків кажанів музею, Nyctalus lasiopterus; $b-$ коробка з тушками кажанів як приклад їхнього збереження у музеї. Фото А. Затушевського. 
Table 1. The number of different types of specimens in the museum's bat collection.

Таблиця 1. Кількість різних типів зразків хіроптерологічної колекції музею

\begin{tabular}{lrrrrr}
\hline Type of museum specimen & Amount & & Type of museum specimen & Amount \\
\cline { 1 - 2 } \cline { 5 - 6 } Mounted specimens & 14 & & Mummies & 23 \\
Study skins & 258 & & Skeletons & 6 \\
Fluid-preserved specimens & 23 & & Skulls &
\end{tabular}

Table 2. Administrative-territorial representation of specimens of bats from Ukraine

Таблиця 2. Адміністративно-територіальна представленість зразків кажанів з території України

\begin{tabular}{|c|c|c|c|c|c|}
\hline Admin. region & Amount & Admin. region & Amount & Admin. region & Amount \\
\hline Volyn & 14 & Luhansk & 8 & Ternopil & 31 \\
\hline Zakarpattia & 84 & Lviv & 113 & AR Crimea & 1 \\
\hline Ivano-Frankivsk & 2 & Rivne & 16 & No specified place* & 8 \\
\hline
\end{tabular}

* Including samples without label.

Table 3. Representativeness of the bat collection according to the geographical origin of specimens

Таблиця 3. Репрезентативність хіроптерологічної колекції за географічним походженням зразків

\begin{tabular}{lrrrrr}
\hline Place of origin & Amount & & Place of origin & Amount \\
\cline { 1 - 1 } Angola (Cabinda Province, Landana) & 1 & & Romania (Dobruja) & 1 \\
Greece & 1 & & Ukraine & 292 \\
Kenya & 23 & & Sri-Lanka & 1 \\
Liberia & 4 & & Africa ("Mapunga") & 1 \\
Madagascar & 1 & & no specified place* & 16 \\
Germany (Thüringen) & 2 & & $*$ Including samples without a label. & \\
\hline
\end{tabular}

During 1909-1910, 19 mummies of the Sundevall's leaf-nosed bat were received, brought by Jerzy Wodzicki from the Great Rift Valley, Kenya. The next enrichment of the collection took place only in 1935-1936, when Professor Jan Hirschler brought four specimens of Neoromicia sp. from Liberia, three of which are still unidentified, and one identified as Neoromicia nanus stampflii. Later on, the museum received a specimen of Nathusius' pipistrelle (Pipistrellus nathusii) collected during World War II by an unknown person in September 1942 in Greece.

The first collection of bats in the museum began to form in 1947 after World War II. However, by 1960 specimens were received occasionally. T. D. Maznova first started systematically collect Chiropterans in the caves of Ternopil oblast, in particular, near Korolivka, Bilche Zolote, and Uhryn villages in the late 1960's. After 1961, other collectors have joined the collection process and the bat collection increased in amount to 88 specimens of 10 specimens within ten years. Although, after 1970 , there was a significant suspension. The museum did not receive new samples of bats until the late 20th century (namely until 1999).

In terms of geographical distribution, as it was already noted, the bat collection is represented, mainly by Ukrainian samples. Only 35 specimens were collected in other countries (continents), in particular 29 in Africa, 1 in Southeastern Asia, 3 in Western Europe, 1 in Central Europe, 1 in Madagascar, and 292 in Eastern Europe (Table 3).

The new "era" in the bat collection's enrichment dates back to the beginning of the 21 st century, when students began to conduct their coursework and graduation theses on bats under the guidance of Associate Professors Eugenia Srebrodolska and Igor Dykyy. The activity in this area increased and, as a result, dead bats found by students eventually were transferred to the museum's collection. Evidently, after 1999-2000 only two specimens arrived to the collection - a Brandt's bat (Myotis brandtii) from the southern suburbs of Lviv city and a common pipistrelle (Pipistrellus pipistrellus) from Haivka village of Shatsk raion, Volyn oblast. 
During 2001-2015, after the first revision of the collection (Bashta, Shydlovskyy, 2001), its volume increased significantly with 135 new specimens of 20 species.

\section{Review on new samples}

New samples obtained during 2001-2007 are characterized by a small amount — up to fourfive specimens per year. However, after 2008, the number of bat biomaterials that enriched the museum's collection increased to an average of 13 specimens per year, with the highest number in 2014. The annual enrichment of the museum's bat collection for the past 15 years is presented on Fig. 2.

The largest number of study skins (47 items) belongs to specimens of the common noctule. One of them was passed to the museum in 2002, and it was collected by V. Mysyuk at the Biological and Geographical Research Station of Ivan Franko National University of Lviv, which is located within Shatsk National Nature Park. Three other specimens were transferred from Uzhhorod in 2011 by Y. Zizda, while the rest of specimens (43) was collected by I. Ivashkiv, O. Kusnezh, and M. Skyrpan in Lviv during 2011-2014. These researchers discovered a place of mass death of bats that occured at the beginning of their spring migration. This place was a hole on the roof of an old house entrance through which the bats would depart. It was located above a pipe from which the funnel of rain and melt-water usually fell after winter. That was the place where young bats used to fall into, while the bottom of the pipe had still been frozen. Chiropterologists had repeatedly talked to the residents of this house about changing the shape of the drainage funnel, which was made only three years after.

However, during this time more than 100 specimens of the common noctule died. Part of this material is still being stored in the freezer chamber of the museum.

The second largest enrichment was by specimens of the serotine bat (Eptesicus serotinus). During the period of studies, 28 specimens were obtained, almost half of which (13) was collected in 2010 by E. Stetskiv and I. Ivashkiv. One or two other specimens of this species, collected in Rivne and Lviv oblasts, were added to the collection as well.

In 2009, the museum's chiropterological collection was enriched with barbastelle specimens (five mummies) prepared by A.-T. Bashta and I. Ivashkiv and collected in the outskirts of Tarakaniv village, Dubensky district, Rivne oblast.

In 2012, one of the authors of this article (O. Kusnezh) enriched the collection of bats with four specimens of Bechstein's bat (Myotis bechsteini), three of which were collected in Ternopil oblast (Kalaharivka village, Gusyatyn district) and one in the Roztochya Biosphere Reserve (IvanoFrankove, Yavorivsky district, Lviv oblast).

\section{Valuable samples}

Thus, the bat collection of ZMD widely represents the bat fauna of the Ukrainian Carpathians and Transcarpathian lowland. Among valuable samples of the collection, it is worth listing the materials from the exposition and stocks that evidence the presence of certain species of bats in Western Ukraine in the middle of the $20^{\text {th }}$ century.

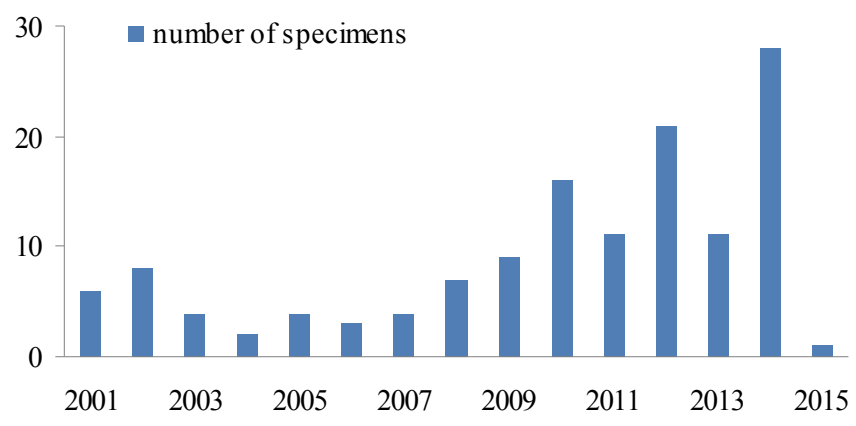

Fig. 2. The number of specimens received by the museum and included into the bat collection during 2001-2015.

Рис. 2. Кількісне представлення надходжень кажанів до хіроптерологічної колекції музею протягом 2001-2015 pp. 
Among them are the whiskered bat (Myotis mystacinus), the lesser mouse-eared bat (Myotis blythii), and the lesser horseshoe bat (Rhinolophus hipposideros) collected in 1947-1960, as well as the common bent-wing bat (Miniopterus schreibersii) (47 specimens) and a number of other species collected in 1961-1962 in Zakarpattia oblast.

Scientifically valuable is the collection of type series of Eptesicus lobatus, which may serve for future examinations of the genus Eptesicus, which is widespread in Eastern Europe, as well as for morphological studies of the post-calcarial lobe of bats and other bat fauna research of the Azov and Donetsk Uplands too.

Equally interesting are collection specimens that represent the tropical fauna and are real evidence of certain species' presence within their range. These findings also provoke new questions for the researchers. In particular, regarding to representatives of the genus Neoromicia, one of which, according to our considerations, belongs to the species $N$. nanus stampflii. However, on the label of our specimen the species is listed as N. stampflii, i.e. the species is identified in the "Mammal Species of the World" (Wilson, Reeder, 2005) as extinct. Nevertheless, our specimens may belong to other three species or subspecies.

\section{References • Література}

Bashta, A.-T., I. Shydlovsky. 2001. Collection of bats (Chiroptera) in B. Dybowski Zoological Museum of the Lviv National University. Scientific Notes of State Natural History Museum. Lviv, 16: 41-45. (In Ukrainian)

[Башта, А.-Т. В., І. В. Шидловський. 2001. Колекція рукокрилих (Chiroptera) Зоологічного музею ім. Б. Дибовського Львівського національного університету. Наукові записки Державного природознавчого музею. Львів, 16: 41-45.]

Donetsk... 2010. Donetsk Serotine (Eptesicus lobatus Zagorodniuk, 2009) - a new species of bats. Stanislavivskyy Naturalist (web-site). https://goo.gl/yECJvR (In Ukrainian) [Пергач... 2010. Пергач донецький (Eptesicus lobatus Zagorodniuk, 2009) - новоописаний вид кажанів. Станіславівський натураліст (веб-сайт). https://goo.gl/yECJvR]

Kusnezh, A. V. 2014. Rare species of bats (Chiroptera) in the collections of the Zoological Museum of Ivan Franko National University of Lviv. In: Zagorodniuk, I. (ed.). Zoological Collections and Museums. National Museum of Natural History, Ukr. Acad. Sci. Kyiv, 63-66. (In Ukrainian) [Кусьнеж, О. В. 2014. Рідкісні види рукокрилих (Chiroptera) у фондах Зоологічного музею Львівського НУ ім. I. Франка. Загороднюк, І. (ред.). Зоологічні колекиії та музеї: Зб. наук. пр. Національний науково-природничий музей НАН України. Київ, 63-66.]

Tatarynov, K. A. 1956. Mammals of the Western Regions of
Ukraine. Vydavn. AS Ukr. SSR, Kyiv, 1-186. (In Ukrainian) [Татаринов, К. А. 1956. Звірі західних областей Украӥни. Вид-во АН УРСР, Київ, 1-186.]

Zagorodniuk, I. 2009. Morphology of post-calcarial lobe in bats and its variation in Eptesicus "serotinus" (Mammalia). Visnyk of the Lviv University. Series Biology, 51: 157-175. (In Ukrainian)

[Загороднюк, I. 2009. Морфологія епіблеми у кажанів та iii мінливість у Eptesicus «serotinus» (Mammalia). Вісник Львівського національного університету. Серія Біологічна, 51: 157-175.]

Zatushevskyy, A. T., I. V. Shydlovskyy, O. S. Zakala, I. V. Dykyy, O. V. Holovachov, M. A. Senyk, Kh. J. Romanova. 2010. Catalogue of the Mammals Collection of the Zoological Museum of Ivan Franko National University of Lviv. Publishing Center of the Ivan Franko National University of Lviv, Lviv, 1-442. (In Ukrainian)

[Затушевський, А. Т., І. В. Шидловський, О. С. Закала, I. В. Дикий, О. В. Головачов, М. А. Сеник, Х. Й. Романова. 2010. Каталог колекцій ссавців Зоологічного музею Львівського національного університету імені Івана Франка. Вид. центр ЛНУ ім. І. Франка, Львів, 1-442.]

Wilson, D. E., D.-A. M. Reeder (eds). 2005. Mammal Species of the World. A Taxonomic and Geographic Reference. Third ed. Johns Hopkins University Press, Washington, London, 1-2142. (https://goo.gl/fUxmtM (10.10.2016). 